\title{
Sm-Nd and Rb-Sr Systematics in Volcanics and Ultramafic Xenoliths From Malaita, Solomon Islands, and the Nature of the Ontong Java Plateau
}

\author{
Miriam Bielski-Zyskind, G. J. Wasserburg, and P. H. Nixon ${ }^{1}$ \\ Lunatic Asylum of the Charles Arms Laboratory, Division of Geological and Planetary Sciences \\ California Institute of Technology
}

\begin{abstract}
A $\mathrm{Rb}-\mathrm{Sr}$ and $\mathrm{Sm}-\mathrm{Nd}$ study was carried out on five ultrabasic inclusions, three alnoite host rocks, and one sample of basalt from Malaita in an effort to determine the isotopic stratigraphy of the mantle in this area. The results of this study show the presence of relatively undepleted mantle segments underlying relatively older depleted upper mantle. The alnoite samples, three megacrysts and one lherzolite inclusion, and the basalt are relatively uniform isotopically and yielded $\varepsilon_{\mathrm{Nd}}(T) \approx+3.5$ and $\varepsilon_{\mathrm{Sr}}(T) \approx-6$ to $+17(T=100 \mathrm{~m}$.y. for the basalt and Iherzolite and $34 \mathrm{~m}$.y. for the rest of the samples). It is suggested that a mantle segment of that isotopic composition exists at a depth of more than $100 \mathrm{~km}$. This mantle segment is relatively undepleted. A lherzolite inclusion with $\varepsilon_{\mathrm{Nd}}(T)=6.6$ is included in the alnoite and indicates the location of a light rare earth element depleted layer overlying a less depleted mantle at a depth of approximately $100 \mathrm{~km}$. The mantle source for the alnoite and basalt cannot be old, depleted oceanic mantle or subducted old continental crust but may come from a relatively young, slightly depleted mantle segment. The isotopic results are compatible with a mixture of about $99 \%$ depleted oceanic mantle homogenized with $1 \%$ continental crust possibly by metasomatic processes. Such a mixture is only slightly fractionated and has $f^{\mathrm{sm} / \mathrm{Nd}} \approx 0.13$ and $f^{\mathrm{kb} / \mathrm{sr}} \approx 0$. Assuming that the basalt is characteristic of the Ontong Java Plateau, a volume greater than $10^{8} \mathrm{~km}^{3}$ of mantle source with $\varepsilon_{\mathrm{Nd}} \sim 3.5, \varepsilon_{\mathrm{Sr}} \sim 0$ was involved. This corresponds to a block of continental crust of $\sim 10^{6} \mathrm{~km}^{3}$ which had to reach a depth greater than $100 \mathrm{~km}$ to produce the proposed nearly homogeneous isotopic mixture. Alternatively, the source of the Ontong Java Plateau may be a segment of a type of young continental crust with the appropriate isotopic signature which was subducted below $100 \mathrm{~km}$. This would not require homogenization with a large volume of depleted mantle.
\end{abstract}

\section{INTRODUCTION}

An alnoite intrusion crops out near the village of Babaru'u in north-central Malaita, the Solomon Islands [Allen and Deans, 1965]. The alnoite is intruded into Lower Cretaceous volcanics which are thought to be the uplifted edge of the Ontong Java Plateau [Kroenke, 1972]. The rock contains a suite of deep-seated ultrabasic xenoliths similar to those found in kimberlites [Nixon and Boyd, 1979]. This rare rock type is not expected to occur in oceanic regions associated with a depleted mantle source.

Sm-Nd and Rb-Sr study was carried out on samples from the alnoite, xenoliths, and the basalt country rock. Isotopic and concentration data were obtained to establish any genetic relations between the alnoite magma and the ultrabasic xenoliths and to throw light on the nature of the Ontong Java Plateau and the underlying mantle. The results were used to reconstruct the evolution and stratigraphy of the mantle in this region.

\section{Geological Setting}

The Solomon Islands are part of the Melanesian borderlands, $a$ chain of island arcs and remnant arcs along the western Pacific Ocean. Malaita (Figure 1), although included geographically among the Solomon Islands, is not part of the arc but is the uplifted edge of the Ontong Java Plateau (OJP) [Kroenke, 1972]. The present position of Malaita is a result of a westward drift of the OJP and a collision with the Solomon block. The collision started $10 \mathrm{~m}$.y. ago and is responsible for the uplifting, folding, and overthrusting of the Malaita island [Coleman and Kroenke, 1981].

\footnotetext{
${ }^{1}$ Now at Department of Earth Sciences, University of Leeds.

Copyright 1984 by the American Geophysical Union.
}

Paper number 3B1929.

0148-0227/84/003B-1929\$05.00
Oceanic plateaus are anomalous regions embedded in the earth's seafloor, located mainly in the western Pacific and the Indian Ocean [see Nur and Ben Avraham, 1982]. They are distinguished by their shallow water depth, thick crust, and low upper crustal seismic velocities. Numerous explanations have been advanced for the nature and origin of the oceanic plateaus. As summarized by Nur and Ben Avraham [1982], they include extinct arcs, abandoned spreading ridges, detached continental fragments, anomalous volcanic piles, hot spots, and uplifted oceanic crust.

The origin of the OJP is somewhat controversial. Its thick crust, up to $40 \mathrm{~km}$, of Lower Cretaceous age and the details of its seismic profile led Carlson et al. [1980] and Nur and Ben Avraham [1982] to propose that the OJP represents a continental block. Nur and Ben Avraham suggested that the plateau is a remnant of Pacifica (a hypothetical eastern extension of Gondwanaland). Kroenke [1974] suggested that the excess thickness of the basaltic rocks represented flood basalts which mark the beginning of continental formation. Nixon and Coleman [1978] and Nixon [1980] support the view that the OJP is a "protocontinent" and predict the existence of true kimberlites under the thicker parts of the plateau. According to Kroenke [1974] and Coleman and Kroenke [1981], the plateau was formed along the crest of a slow spreading ocean ridge. The slow spreading, according to this view, is responsible for the thick crust of the plateau. In this model the magmas which formed the plateau would presumably be derived from depleted oceanic mantle [Tatsumoto et al., 1965; Gast, 1968], similar to other mid-ocean ridge basalts (MORB) yielding a characteristic, isotopic signature of old, depleted mantle [DePaolo and Wasserburg, 1976a; Richard et al., 1976]. From their study of seismic data, Hussong et al. [1979] proposed that the OJP consists of normal oceanic crust simply expanded by a factor of 5 in thickness. This would also show the above isotopic characteristics. 


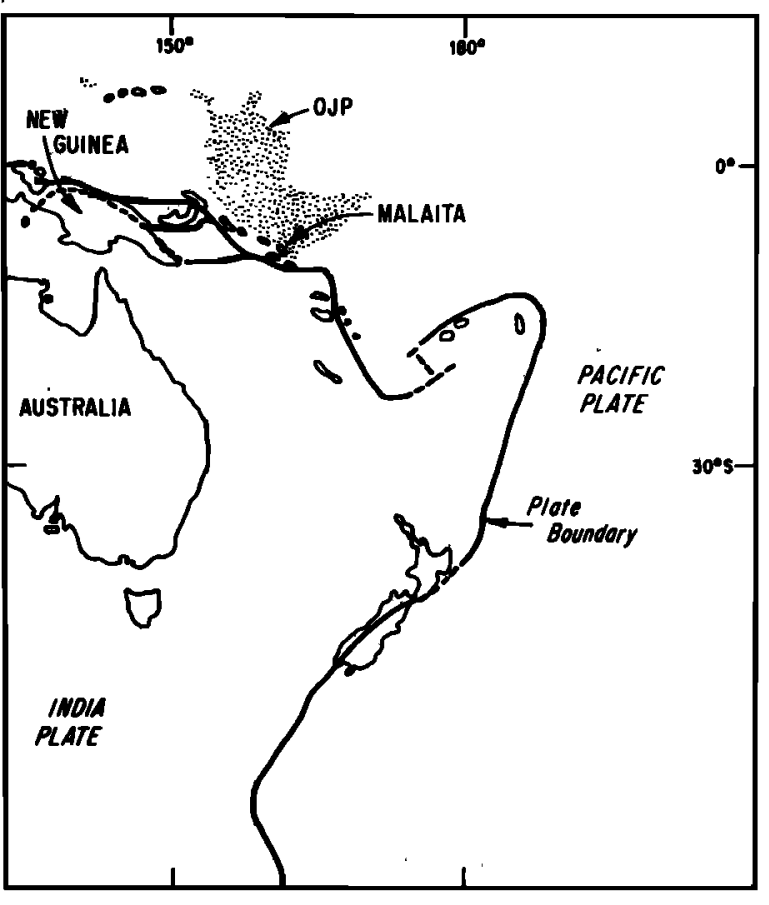

Fig. 1a

Fig. 1. Location of (a) Malaita (M) and (b) the Ontong Java Plateau (OJP) in the southwest Pacific [after Coleman and Packham, 1976].

Hughes and Turner [1977] described the basaltic rocks of Malaita. The more extensive basalts (more than $2 \mathrm{~km}$ are exposed in central Malaita) belong to the old, tholeiitic phase assumed to be part of the Lower Cretaceous OJP volcanism. The younger (Upper Cretaceous to Eocene) alkalic phase is much less voluminous and is restricted only to the southern part of the island. On the basis of chemical compositions, Hughes and Turner pointed out that the old tholeiitic phase (consisting of flows of nonpillowed and pillowed lavas) shows similarities to both oceanic island tholeiites and ocean ridge tholeiites. On the basis of field evidence, they favor the idea that the Malaita basalts resemble oceanic island volcanism because they consider it unlikely that the basalts were derived from extensional rift features where dikes would be expected to be much more common. From surveying these hypotheses it appears that there is no consensus concerning the nature and origin of the OJP. It is, however, remarkable that no xenoliths of continental crust were found in the basalts nor were any found among the xenoliths of the alnoite which intruded the OJP during the Tertiary.

\section{The Alnoite}

Field evidence [Nixon and Coleman, 1978] suggests that the alnoite is a pipelike intrusion emplaced in steeply folded Upper Cretaceous and lower Tertiary mudstones and limestones (Figure 2). These sedimentary rocks are found as xenoliths in the alnoite [Nixon and Boyd, 1979]. This age relationship is in accord with the U-Pb age of $34 \mathrm{~m} . \mathrm{y}$. [Davis, 1978] obtained by dating a zircon xenocryst from the alnoite. The Cretaceoùs sediments which are crosscut by the alnoite overlie basalt, pillow lavas, and tuffs (the Alite Volcanics) of tholeiitic composition [Hughes and Turner, 1977].

The alnoite, which is describe in detail by Allen and Deans [1965] and Nixon et al. [1980], consists mainly of fragmented rocks grading from tuffs to soft breccias, but a fresh hard aphanitic variety is also present. Primary minerals in the fresh alnoite are olivine $\left(\mathrm{Fo}_{85}\right)$ 25-35\%, melilite up to $30 \%$, clinopyroxene, phlogopite (5-55\%), perovskite, and spinel. Accessories are nepheline, melanite, and apatite. The fragmented rocks are rich in calcite (more than $50 \%$ ) and contain coarse, rounded phlogopite $(>1 \mathrm{~cm})$. Coarse phlogopite is often found in the cores of autoliths, which are subspherical structures composed of alnoitic magma wrapped around a rock or mineral inclusion. Nixon et al. [1980] suggested that the alnoite is a primary melt of a pyrolite-type mantle formed by approximately $4 \%$ partial melting at depths greater than 120 $\mathrm{km}$, under high $\mathrm{CO}_{2}$ pressure. The only previous isotopic data on this rock type from the same locality were a ${ }^{143} \mathrm{Nd} /{ }^{144} \mathrm{Nd}$ ratio determination by Basu and Tatsumoto [1980]. These workers compared this result with kimberlites and concluded that they came from a different source.

\section{THE XenOliths}

As reported by Nixon and Boyd [1979], the proportion of country rock sedimentary fragments, ultramafic xenoliths, and discrete monomineralic nodules in the alnoite varies but is generally greater than $10 \%$. Lherzolites predominate among

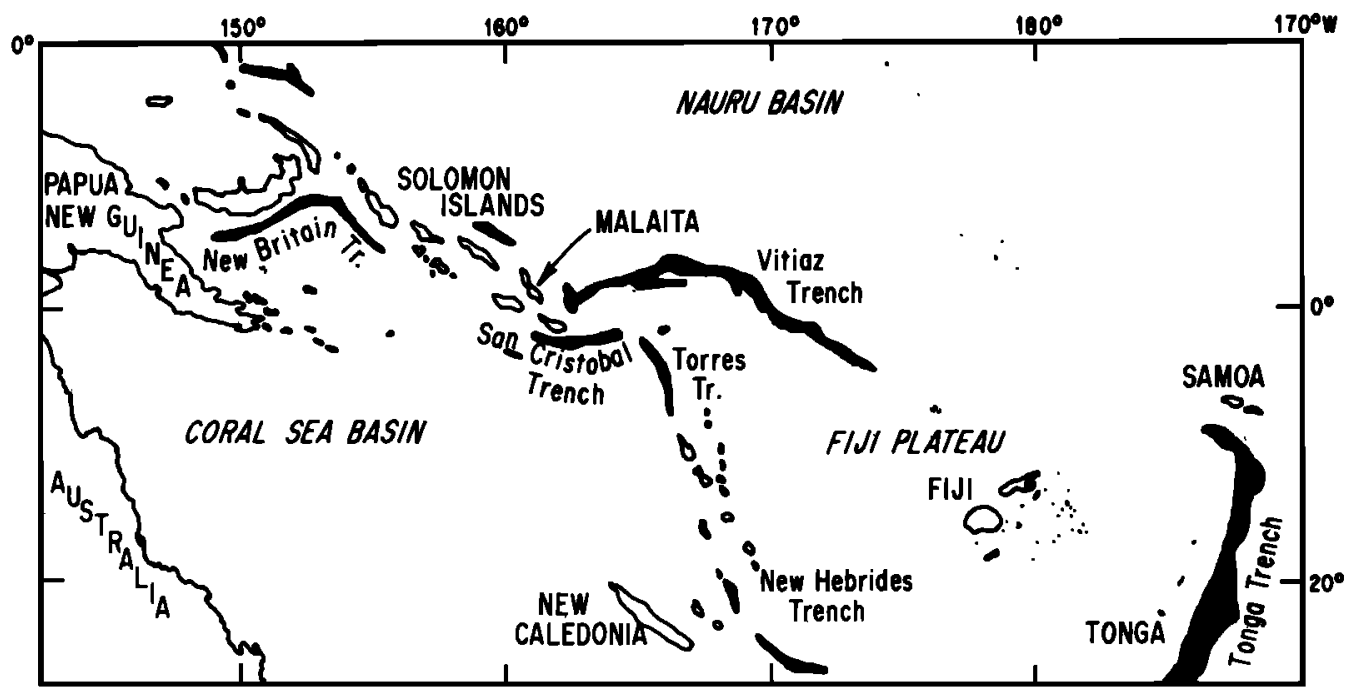

Fig. 1b 


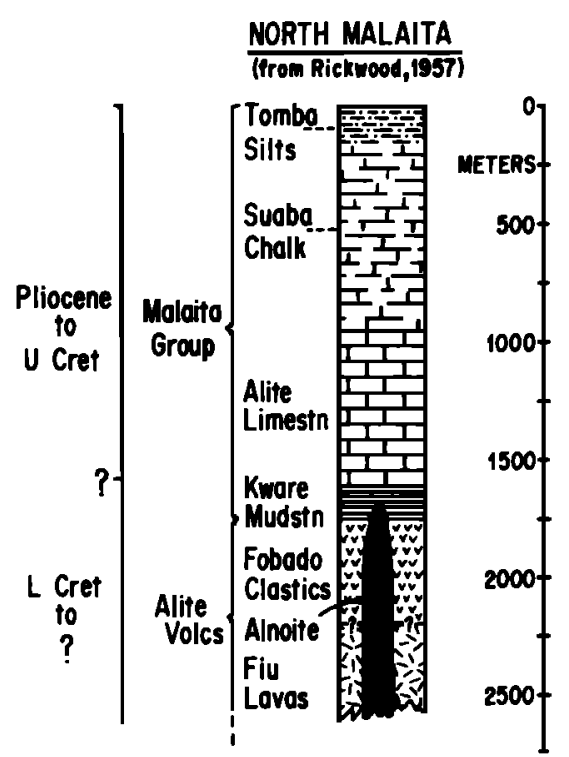

Fig. 2. Stratigraphic section of the upper crust in northern Malaita (Solomon Islands) using information from Rickwood [1957] and other sources referred to in the text.

the mantle ultramafics. They consist of olivine $(50-70 \%)$, orthopyroxene (10-35\%), and clinopyroxene (5-40\%). Some of the specimens might have garnet (up to $18 \%$ ) and/or spinel or chromite (up to $7 \%$ ). The discrete monomineralic nodules are large, rounded, single crystals, megacrysts of garnet, cpx, opx, and ilmenite. Nixon and Boyd used the xenoliths and megacrysts to construct a paleogeotherm. Compared with similarly derived geotherms from garnet-bearing nodules in continental kimberlites, the Malaita geotherm has a higher gradient, reflecting a higher heat flow. A high-temperature inflection is interpreted as the occurrence of the lithosphereasthenosphere transition at a depth of $110 \mathrm{~km}$. Figure 3 (taken from Nixon and Boyd [1979]) gives their proposed depth profile of the lithosphere and top of asthenosphere under Malaita. Not all of these depths are well defined by geobarometers. The discrete nodules are believed to come from the top of the asthenosphere at a depth of $110-120 \mathrm{~km}$. The lherzolites are considered to be respresentative of the overlying lithosphere from 110 to $60 \mathrm{~km}$ depth. They include both deeper seated depleted and undepleted samples as determined by large ion lithophile (LIL) element abundances. The alnoitic magma must have cut across all of these lithic units during its ascent.

\section{SAMPLES}

Ten samples from the Malaita alnoite and an older basalt were used in this study. They include four alnoite samples, five xenoliths and megacrysts found in the alnoite, and one sample of the country rock basalt believed to be part of the Lower Cretaceous volcanic phase of the OJP. A short description of the samples is given below. More information can be found in the references cited before. No depth assignment can be made on rocks in which garnet is absent.

\section{MALAITA OCEANIC MODEL}

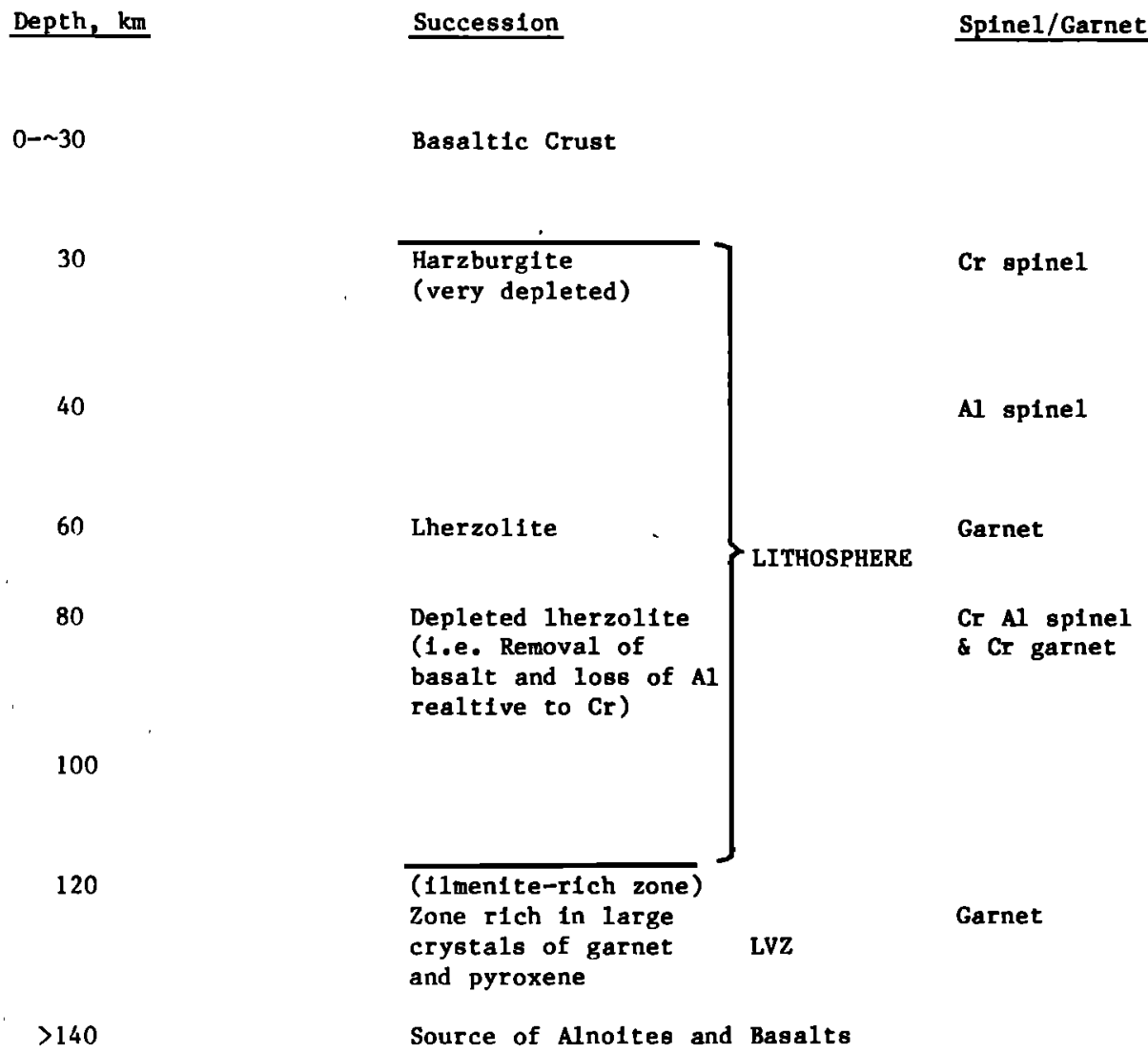

Fig. 3. Stratigraphic cross section of the lower crust mantle underlying Malaita from a study of xenoliths by Nixon and Boyd [1979] (slightly modified). 
TABLE 1. Rb-Sr and Sm-Nd Analytical Data

\begin{tabular}{|c|c|c|c|c|c|c|c|c|c|c|}
\hline & $\begin{array}{l}\mathrm{Rb} \text {, } \\
\mathrm{ppm}\end{array}$ & $\begin{array}{l}\mathrm{Sr}, \\
\text { ppm }\end{array}$ & $\begin{array}{l}\text { Sm, } \\
\text { ppm }\end{array}$ & $\begin{array}{l}\text { Nd, } \\
\text { ppm }\end{array}$ & $f^{\mathbf{R b} / \mathbf{S r}}$ & $f^{\mathrm{Sm} / \mathrm{Nd}}$ & ${ }^{87} \mathrm{Sr} /{ }^{86} \mathrm{Sr}$ & ${ }^{143} \mathrm{Nd} /{ }^{144} \mathrm{Nd}$ & $\varepsilon_{\mathrm{Sr}}(T)^{*}$ & $\varepsilon_{\mathrm{Nd}}(T)^{*}$ \\
\hline \multicolumn{11}{|c|}{ Alnoites } \\
\hline PHN-3935 & 79.1 & 1380 & 19.4 & 100 & +1.00 & -0.40 & $0.70461 \pm 3$ & $0.511992 \pm 25$ & 1.0 & 3.2 \\
\hline PHN-3855 & 61.4 & 3055 & 17.2 & 89.7 & -0.30 & -0.40 & $0.70467+6$ & $0.511956 \pm 28$ & 2.6 & 2.5 \\
\hline PHN-3554 & $32 \dagger$ & 827 & $13 \dagger$ & 64.4 & +0.35 & -0.34 & $0.70455 \pm 7$ & $0.512002 \pm 28$ & 0.5 & 3.3 \\
\hline PHN-3544 & $74 \dagger$ & $1188 \ddagger$ & $24.4 \S$ & $143.7 \S$ & +1.18 & -0.47 & $\ldots$ & $0.512802 \pm 358$ & $\cdots$ & 3.7 \\
\hline \multicolumn{11}{|c|}{ Xenoliths } \\
\hline $\begin{array}{c}\text { PHN-3995 } \\
\text { 1herzolite }\end{array}$ & $0.5 \dagger$ & 17.1 & $0.2 \dagger$ & 0.093 & +0.02 & -0.33 & $0.70510 \pm 5$ & $0.512167 \pm 27$ & 8.5 & 6.5 \\
\hline $\begin{array}{c}\text { PHN-3852 } \\
\text { cpx from } \\
\text { 1herzolite }\end{array}$ & $0.03 \dagger$ & $48.8 \dagger$ & $2.1 \dagger$ & $12.0 \dagger$ & -0.98 & -0.46 & $0.70440 \pm 7$ & $0.511946 \pm 15$ & -0.9 & 2.3 \\
\hline $\begin{array}{l}\text { PHN-3861 } \\
\text { gt-pyroxenite }\end{array}$ & $13 \dagger$ & $317 \uparrow$ & $1.1 \dagger$ & $3.7 \dagger$ & +0.43 & -0.08 & $0.70571 \pm 2$ & $0.512002 \pm 15$ & 16.9 & 3.1 \\
\hline $\begin{array}{c}\text { PHN-3986A } \\
\text { garnet }\end{array}$ & $0.72 \dagger$ & 10.2 & 1.18 & 1.48 & +1.47 & +1.47 & $0.70453 \pm 4$ & $0.512086 \pm 15$ & -0.4 & 3.4 \\
\hline PHN-3968 & $1.9 \dagger$ & $107 \dagger$ & $1.9 \dagger$ & 6.96 & -0.38 & -0.15 & $0.70406 \pm 4$ & $0.512055 \pm 14$ & -6.0 & 4.2 \\
\hline \multicolumn{11}{|c|}{ Basalt } \\
\hline PHN-3916 & $0.37 \dagger$ & 148 & $3.3 \dagger$ & 10.8 & -0.91 & -0.05 & $0.70440 \pm 3$ & $0.512036 \pm 22$ & 0.1 & 3.8 \\
\hline
\end{tabular}

* $T=100$ m.y. for the basalt (PHN-3916) and $T=34$ m.y. for all the rest of the samples.

fConcentration determined by aliquot only (see text).

$\ddagger$ Data from Nixon et al. [1980].

§Data from Basu and Tatsumoto [1980], using ${ }^{150} \mathrm{Nd} /{ }^{144} \mathrm{Nd}=0.23643$ for normalization of isotopic data.

$P H N-3935$. Tough fresh alnoite. Partly serpentinized olivine phenocrysts. Minor calcite is associated with deformed phlogopite.

$P H N-3855$. Tough fresh alnoite. About $30 \%$ melilite. No calcite. A few phlogopite crystals in centers of autholiths. Traces of sulfides.

$P H N-3554$. Soft alnoite agglomerate with spherical autoliths. About $50 \%$ calcite.

$P H N-3544$. Fresh tough alnoite (description and chemical analysis from Nixon et al. [1980]).

$P H N-3995$. Tough unserpentinized spinel lherzolite (olivine $60-70 \%, \mathrm{cpx} \sim 30 \%$ ) with a deformational texture: defined by layers of recrystallized cpx granules $(\sim 1 \mathrm{~mm})$ and much coarser, aligned spinels and opx (up to $7 \mathrm{~mm}$ ). Spinel granules $(0.1 \mathrm{~mm})$ are conspicuously developed at grain boundaries.

$P H N-3852$. Cpx (chromium diopside) separated from a spinel lherzolite: olivine $(60 \%)$, opx $(20 \%)$, cpx $(5 \%)$, serpentine and calcite rims surrounding fresh grains.

$P H N-3861$. Coarse garnet-opx-cpx xenolith with cumulate texture. Garnet is highly kelyphytic.

PHN-3986A. Discrete garnet (megacryst). Fractured but fresh.

$P H N-3968$. Discrete cpx (megacryst) (originally 1-kg nodule). A few spherical inclusions containing phlogopite and serpentine.

PHN-3916. Country rock basalt. Phenocrysts of plagioclase and cpx in a matrix of pl, cpx, and glass.

\section{Analytical Method}

The analytical method used for the determination of $\mathbf{R b}, \mathbf{S r}$, $\mathrm{Nd}$, and $\mathrm{Sm}$ concentration as well as $\mathrm{Sr}$ and $\mathrm{Nd}$ isotopic composition is described by Papanastassiou et al. [1977] and DePaolo [1978]. Element concentrations in some of the samples (Table 1) were determined only by an aliquot run in which the four elements are spiked and measured in a single mass spectrometric run prior to chemical separation. Uncertainties associated with these concentration values are typically better than $5 \%$. Samples which were totally spiked and separated have concentrations determined to better than $\sim 0.1 \%$.

Sample PHN-3995, because of its low rare earth element (REE) concentration, was processed in a somewhat different way: $1 \mathrm{~g}$ of the sample powder was dissolved, aliquot concentrations were determined, and accurate spiking was performed the usual way. Then the sample solution was split into two fractions: $0.1 \mathrm{~g}$ was processed for $\mathbf{R b}-\mathrm{Sr}$ determinations. To the remaining $0.9 \mathrm{~g}$, a few milliliters of pure ammonia solution was added until iron precipitation as $\mathrm{Fe}(\mathrm{OH})_{3}$ was completed. The REE were adsorbed on this precipitate [Goldberg et al., 1963] and more than $95 \%$ of the REE, as determined for Eu and Nd, were recovered. This removed most of the other major elements. The precipitate was centrifuged, separated from the supernate and dissolved in HCl. This solution, containing the REE fraction, was then processed through the separation columns following the usual procedure.

Rather pure cpx was hand-picked from a lherzolite (PHN3852) and then cleaned from small, attached olivine and possible alteration products by soaking in HF solution. Olivine disintegrated, and the cpx remained unattacked.

\section{DATa Representation}

$\mathrm{Rb}-\mathrm{Sr}$ and $\mathrm{Sm}-\mathrm{Nd}$ data are summarized in Table 1 . The enrichment factors $f^{\mathrm{Rb} / \mathrm{Sr}}$ and $f^{\mathrm{Sm} / \mathrm{Nd}}$ provide a measure of the deviation of $\mathrm{Rb} / \mathrm{Sr}$ and $\mathrm{Sm} / \mathrm{Nd}$ of a rock from a model primitive undifferentiated bulk earth source composition. An estimate for the REE composition of undifferentiated bulk earth (CHUR) was given by DePaolo and Wasserburg [1976]. The revised values for CHUR, given by Jacobsen and Wasserburg [1980] and Wasserburg et al. [1981] will be used here. The unfractionated reservoir values (UR) for the bulk earth $\mathbf{R b}$ and $\mathrm{Sr}$ are taken from DePaolo and Wasserburg [1976b] and 
O'Nions et al. [1977].

$$
\begin{gathered}
f^{\mathrm{Sm} / \mathrm{Nd}} \equiv\left[(\mathrm{Sm} / \mathrm{Nd})_{m} /(\mathrm{Sm} / \mathrm{Nd})_{\mathrm{CHUR}}\right]-1 \\
\left({ }^{147} \mathrm{Sm} /{ }^{144} \mathrm{Nd}\right)_{\mathrm{CHUR}}=0.1967 \\
f^{\mathrm{Rb} / \mathrm{Sr}} \equiv\left[(\mathrm{Rb} / \mathrm{Sr})_{\mathrm{m}} /(\mathrm{Rb} / \mathrm{Sr})_{\mathrm{UR}}\right]-1 \\
\left({ }^{87} \mathrm{Rb} /{ }^{86} \mathrm{Sr}\right)_{\mathrm{UR}}=0.0827
\end{gathered}
$$

Here " $m$ " represents the measured value. Isotopic ratios are expressed in $\varepsilon$ notation [DePaolo and Wasserburg, 1976], where $\varepsilon(0)$ is the measured deviation in parts of $10^{4}$ of the isotopic ratio from present-day CHUR or UR values.

$$
\begin{gathered}
\varepsilon^{\mathrm{Nd}}(0)=\left[\frac{\left({ }^{143} \mathrm{Nd} /{ }^{144} \mathrm{Nd}\right)_{m}}{\left({ }^{143} \mathrm{Nd} /{ }^{144} \mathrm{Nd}\right)_{\mathrm{CHUR}}}-1\right] \times 10^{4} \\
\left({ }^{143} \mathrm{Nd} /{ }^{144} \mathrm{Nd}\right)_{\mathrm{CHUR}}=0.511847 \\
\varepsilon^{\mathrm{Sr}}(0)=\left[\frac{\left({ }^{87} \mathrm{Sr} /{ }^{86} \mathrm{Sr}\right)_{m}}{\left({ }^{77} \mathrm{Sr} /{ }^{86} \mathrm{Sr}\right)_{\mathrm{UR}}}-1\right] \times 10^{4} \\
\left({ }^{87} \mathrm{Sr} /{ }^{86} \mathrm{Sr}\right)_{\mathrm{UR}}=0.7045
\end{gathered}
$$

The evolution of the isotopic deviation with age can be calculated for any age $(T)$ of interest. A useful approximation [DePaolo and Wasserburg, 1976] was used to calculate those values:

$$
\begin{gathered}
\varepsilon_{\mathrm{Nd}}(T)=\varepsilon_{\mathrm{Nd}}(0)-Q_{\mathrm{Nd}} f^{\mathrm{Sm} / \mathrm{Nd}} T \\
Q_{\mathrm{Nd}}=24.74 \mathrm{aeon}^{-1} \\
\varepsilon_{\mathrm{Sr}}(T)=\varepsilon_{\mathrm{Sr}}(0)-Q_{\mathrm{Sr}} f^{\mathrm{Rb} / \mathrm{Sr}} T \\
Q_{\mathrm{Sr}}=16.70 \mathrm{aeon}^{-1}
\end{gathered}
$$

The values of $\varepsilon(T)$ for the alnoite and xenolith samples was calculated with $T=34 \mathrm{~m} . \mathrm{y}$., the U-Pb age of the alnoite intrusion. For the xenoliths and megacrysts this is a minimum age but is useful for investigating the alnoite-xenoliths genetic relations. The $\varepsilon(T)$ for the basalt sample was calculated with $T=100 \mathrm{~m} . \mathrm{y}$. This is an estimate for the age of the intrusive volcanic episode, responsible for the formation of the Ontong Java Plateau. The stratigraphic age of those volcanics is at least as old as Early Cretaceous [Hughes and Turner, 1977]. As the $f^{\mathrm{sm} / \mathrm{Nd}}$ value of the basalt is close to zero, $\varepsilon_{\mathrm{Nd}}(T)$ is not sensitive to a possible error in the chosen age.

We will show that the resulting $\varepsilon(T)$ values calculated with the above mentioned ages are very similar for all the samples (excluding only the lherzolite). Using another set of ages will cause a scatter of $\varepsilon(T)$ values. We will conclude that the homogeneity of $\varepsilon_{\mathrm{Nd}}(T)$ is not accidental and indicates genetic relations between the samples.

\section{ResUlts}

\subsection{The Alnoite and Basalt}

The alnoite samples are all LIL and REE enriched by a large factor in comparison to any bulk earth values or even to average continental crustal rocks: up to $80 \mathrm{ppm} \mathrm{Rb}, 3050 \mathrm{ppm}$ $\mathrm{Sr}, 25 \mathrm{ppm} \mathrm{Sm}$, and $145 \mathrm{ppm} \mathrm{Nd}$ (Table 1). Some of these samples have $\mathrm{La} / \mathrm{Lu}$ of $\sim 45$ [Nixon et al., 1980]. Samples PHN-3935, PHN-3855, and PHN-3544 are very similar in their concentration levels except for the $\mathrm{Sr}$ in PHN-3855 which is much higher, possibly due to a high melilite content. PHN-3554 does not show such high enrichments. This sample is a soft agglomerate with $50 \%$ calcite, whereas the other three samples are aphanitic alnoite, poor or devoid of calcite. We believe that as calcite is low in REE, it is a dilutant for PHN3554. The $f^{\mathrm{sm} / \mathrm{Nd}}$ values for all the samples are very similar around -0.4 reflect a high light rare earth element (LREE) enrichment compared with a chondritic $\mathrm{Sm} / \mathrm{Nd}$ ratio. A more complete REE spectrum had previously been measured by Nixon et al. [1980], who showed the high LREE enrichment. The high LIL and REE content and strong LREE enrichment are very typical of alkali basalts, kimberlites, and carbonatites [Haskin et al., 1966; Kay and Gast, 1973]. This is an additional indication that the alnoite belongs genetically to this group of rocks.

The $f^{\mathrm{Rb} / \mathrm{Sr}}$ values range from -0.3 to +1.18 . Leaving out the only negative value $(-0.3)$ corresponding to the meliliterich sample (PHN-3855), the mean $f^{\mathrm{Rb} / \mathrm{Sr}}$ of the alnoite is +0.85 . A melt with such $\mathrm{Rb} / \mathrm{Sr}$ enrichment can be derived from a mantle source with bulk earth composition $\left(f^{\mathrm{Rb} / \mathrm{Sr}} \equiv 0\right)$ by $\sim 3 \%$ of partial melting (calculated using bulk partition coefficients of $D_{\mathrm{Rb}}=0.0025, D_{\mathrm{Sr}}=0.033$ ) (taken from literature list as given by Jacobsen and Wasserburg, [1979a]).

$\mathrm{The} \mathrm{Sr}$ and $\mathrm{Nd}$ isotopic compositions are very close to each other for all four alnoite samples. The $\varepsilon_{\mathrm{Sr}}(34 \mathrm{~m} . \mathrm{y}$.) is close to zero, suggesting an unfractionated source close to the bulk earth value. The $\varepsilon_{\mathrm{Nd}}(34 \mathrm{~m} . \mathrm{y}$.) is $2.5-3.7$, indicating some timeintegrated LREE depletion but far smaller than for typical depleted oceanic mantle. These isotopic values are similar to the $\varepsilon_{\mathrm{Sr}}(100$ m.y. $)=0.1$ and $\varepsilon_{\mathrm{Nd}}(100$ m.y. $)=3.8$ of the basalt sample, which is believed to represent the bulk of the OJP. Despite the age difference, the sources for the alnoite and basalt can be treated as isotopically identical sources because of the short time interval. The isotopic composition of the mantle source will not change by more than one epsilon unit for $\mathrm{Nd}$ and 10 epsilon units for $\mathrm{Sr}$ within 0.1 aeon, providing $\left|f^{\mathrm{Sm} / \mathrm{Nd}}\right|<0.4$ and $f^{\mathrm{Rb} / \mathrm{st}}<6$, which is the case for all the major tectonic environments, excluding the upper continental crust [DePaolo and Wasserburg, 1979a].

Figure 4 shows the isotopic data for the Malaita alnoite and basalt in comparison with oceanic basalt values. The distinction of the Malaitan values from MORB and island arc values is obvious. It is therefore concluded that the source of the alnoite and basalt is not an old time-integrated depleted mantle such as MORB and island arc basalt sources. The high LIL and REE contents of the alnoite relative to bulk earth concentrations of that found in MORB indicate an undepleted source as well; however, such chemical enrichment in kimberlites and alkali-basalts is often attributed to metasomatism of the source region as the mechanism for concentrating the incompatible elements [Boettcher et al., 1979]. The isotopic compositions, nevertheless, clearly indicate that even if the origin of the alnoite involved multistage chemical enrichment processes, the sources involved were not of an old, depleted nature.

The Malaita sample falls to the right of the mantle array close to the field of ocean islands (Figure 4). Ocean islands display a wide range of $\varepsilon_{\mathrm{Nd}}-\varepsilon_{\mathrm{Sr}}$ values, and deviations from the mantle array are not rare. For instance, the Azores, Samoa, and Society islands' basalt values [Hawkesworth et al., 1979; White and Hofmann, 1982] are shifted to the right of the mantle array, thus including the Malaitan values within their range. The Malaitan isotopic characteristics are thus not unique and can be found in oceanic environments. DePaolo and Wasserburg [1979b] and Wasserburg and DePaolo [1979] presented the possibility that some oceanic islands represented plumes from an undepleted lower mantle which were partially contaminated or mixed with overlying oceanic mantle during 


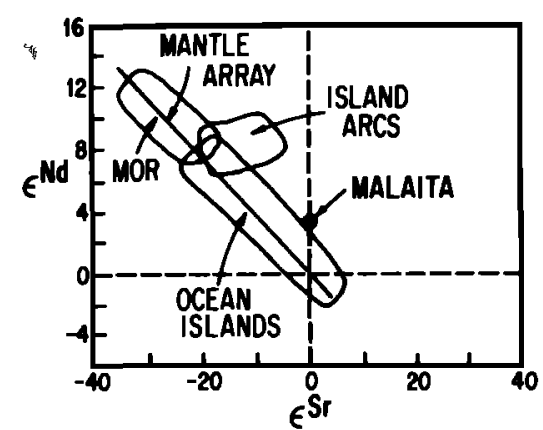

Fig. 4. A $\varepsilon_{\mathrm{Sr}}-\varepsilon_{\mathrm{Nd}}$ diagram showing the Malaita basalt and alnoite data in comparison with the principal oceanic basalt sources.

ascent. White and Hofmann [1982] propose a reinjection of crustal material into the mantle as an explanation of the observed isotopic values for ocean islands. The $\varepsilon_{\mathrm{Sr}}$ and $\varepsilon_{\mathrm{Nd}}$ values of the Malaitan samples differ conspicuously from negative $\varepsilon_{\mathrm{Nd}}$ and high $\varepsilon_{\mathrm{Sr}}$ values typical of old continental crust [McCulloch and Wasserburg, 1978]. There is no hint in the available data from Malaita of the isotopic signature of old continental crust. If subducted old continental crust is a component, it must be sufficiently mixed with other components so that no partial melts, with an old continental signature, are produced. This indicates that no direct melting of typical old continental material is involved either as parental material or as an incompletely homogenized contaminant.

\subsection{The Xenoliths and Megacrysts}

Five samples of mantle nodules found in the alnoite were analyzed (Table 1). All the samples, excluding PHN-3995, show undepleted contents of $\mathrm{Rb}, \mathrm{Sr}, \mathrm{Sm}$, and $\mathrm{Nd}$, compared with chondritic levels [Haskin et al., 1966; Mason, 1971]. The lherzolite, PHN-3995, is highly depleted in REE, having Sm and $\mathrm{Nd} 10$ and 6 times lower than chondritic values, respectively. Note that of the "undepleted" samples, only PHN-3861 represents a total rock; the other samples are individual mineral phases so that no strong quantitative comparison regarding concentration levels can be made.

The $\varepsilon_{\mathrm{sr}_{\mathrm{r}}}(34 \mathrm{~m} . \mathrm{y}$.) values of the five samples lie within a range of -6.0 to +17.0 and scatter around zero, similar to the alnoite and basalt samples, and none of the samples has low $\varepsilon_{\mathrm{Sr}}$ typical of depleted oceanic mantle or high $\varepsilon_{\mathrm{Sr}}$ typical of continental crust. The range of $\varepsilon_{\mathrm{Nd}}(34 \mathrm{~m} . \mathrm{y}$.) for the garnet (PHN-3986A), the cpx (PHN-3968), and the gt-pyroxenite (PHN-3861) is 3.1-4.2, essentially the same as the alnoite value. The $\varepsilon_{\mathrm{Nd}}$ ( $34 \mathrm{~m} . \mathrm{y}$.) of the cpx from lherzolite PHN-3852 is +2.3 , but at 100 m.y. the value $\varepsilon_{\mathrm{Nd}}(100 \mathrm{~m} . \mathrm{y})=$.3.1 and is similar to the basalt value.

The isotopic similarity between the alnoite, the megacrysts, and the gt-pyroxenite might be a result of either isotopic equilibration of these inclusions with the alnoite magma or represent the original mantle layer through which the alnoite passed. The megacrysts, which are homogeneous and unzoned, could not maintain their isotopic similarity at a time substantially prior to $34 \mathrm{~m} . y$. because they have very different $f^{\mathrm{Sm} / \mathrm{Nd}}$ values. The garnet has $f^{\mathrm{Sm} / \mathrm{Nd}}=1.47$, and the $\mathrm{cpx}$ has $f^{\mathrm{Sm} / \mathrm{Nd}}=-0.15$ so that they would differ by one epsilon unit if their age was $60 \mathrm{~m} . y$. instead of $34 \mathrm{~m} . \mathrm{y}$. The observed $D_{\mathrm{S}_{\mathrm{m}}}{ }^{{ }^{\mathrm{ppx}-\mathrm{gt}}}=1.6$ and $D_{\mathrm{Nd}}{ }^{\text {cpx-gt }}=4.7$ are consistent with values obtained experimentally [Harrison, 1981] and observed in natural lherzolites [Shimizu, 1975]. The megacrysts thus seem to be in chemical equilibrium with each other, as demonstrated by the REE distribution coefficients. The megacrysts, however, cannot be in chemical equilibirum with the very REE rich alnoite magma if we consider the distribution coefficients obtained experimentally by Harrison [1981]. The presence of a $\mathrm{H}_{2} \mathrm{O}-\mathrm{CO}_{2}$ vapor phase which concentrate REE [Wendlandt and Harrison, 1979; Mysen, 1979] would facilitate equilibration. Substantial amount of calcite and phlogopite in the alnoite demonstrates the existence of volatile components and suggests the presence of a separate volatile phase in the alnoite magma. Intuitively, we would expect that these volatile components would also facilitate the equilibration of the megacrysts with the alnoite which does not appear to be the case.

In considering the possible origin of kimberlites from "ordinary" mantle, Kramers et al. [1981] have argued that the partition coefficients between kimberlitic liquids and clinopyroxenes may be very low. If this is correct, then our inference using the data of Harrison [1981] is not valid, and the megacrysts could be in chemical equilibrium with the melt. The wide range of possible distribution coefficients presently available or considered plausible do not permit us to draw a firm conclusion on this matter. However, $f^{\mathrm{sm} / \mathrm{Nd}}$ values of the megacrysts range from 0 to -0.35 , and therefore the isotopic composition of the megacrysts would not be the same for an age much different from that of the kimberlite intrusion. Regardless of any particular model, we infer from the isotopic similarity that the megacrysts were isotopically equilibrated at or near the time of emplacement either with the volatile-rich alnoite or were produced from partial melts of an overlying mantle layer with the same isotopic characteristics (e.g., only slightly depleted).

The lherzolite $(\mathrm{PHN}-3995)$ has $\varepsilon_{\mathrm{Nd}}(34$ m.y.) $=+6.5$. This value is compatible with the low REE content of this rock (similar to more depleted mantle) and indicates a timeintegrated LREE depletion which is substantially greater than for the alnoite. There is, however, a contradiction between these inferred depletions and the low $f^{\mathrm{Sm} / \mathrm{Nd}}$ value of -0.33 . This $f^{\mathrm{Sm} / \mathrm{Nd}}$ value, indicating LREE enrichment, points to a further complication in the history of the lherzolite sample and might point to a contamination (mechanical or chemical alteration) by a component with a LREE-enriched pattern such as the alnoite. If these results are due to the partial contamination with the alnoite, then the $\varepsilon_{\mathrm{Nd}}$ and $\varepsilon_{\mathrm{Sr}}$ value of the original lherzolite must have been substantially greater. Because of the very low $\mathrm{Nd}$ concentration, the $\varepsilon_{\mathrm{Nd}}$ values would be most susceptible to such an effect and bring the original uncontaminated value even further toward a MORBtype source value. In summary, this sample shows that lherzolite layer or segment with the characteristics of a rather old, depleted mantle source was traversed by the alnoite magma. This depleted layer has affinities with old, depleted oceanic mantle and may represent a residue left from forming MORBtype magmas.

In contrast, cpx from the lherzolite PHN-3852 $\varepsilon_{\mathrm{Nd}}(34 \mathrm{~m} . \mathrm{y}$.) has a value $(+2.3)$ which is slightly lower than the values found for the alnoites. If this lherzolite was partially equilbrated with the alnoite, then its original $\varepsilon_{\mathrm{Nd}}$ values was even lower. It therefore points to a relatively undepleted zone, either not much different from the alnoite source or to an undepleted or enriched source.

\section{Discussion}

The $\mathrm{Rb}-\mathrm{Sr}$ and $\mathrm{Sm}-\mathrm{Nd}$ data indicate that the mantle underlying the OJP is heterogeneous and layered with a large volume of relatively undepleted material (the basalt and al- 
noite source) underlying an old depleted zone (PHN-3995). Combining the isotopic data with the stratigraphy proposed by Nixon and Boyd [1979] (Figure 3), a two-layer depth profile can be matched with the analyzed samples: The alnoite is inferred to have originated at a depth exceeding $120 \mathrm{~km}$. This zone must represent a segment of relatively undepleted mantle (i.e., has not been depleted in LIL elements). Overlying this zone, at a depth of $\sim 100 \mathrm{~km}$, LIL element depleted lherzolites with rather high $\varepsilon_{\mathrm{Nd}}$ such as PHN-3995 were picked up by the alnoite magma. The $\varepsilon_{\mathrm{Nd}}$ value is indicative of a rather old, depleted source. At a possibly shallower depth, $60-80 \mathrm{~km}$, lherzolites such as PHN-3852 were picked up which do not represent an ancient, depleted source. This zone does not have the long-term LREE enrichment of PHN-3995. If we ignore contamination as an explanation of the "undepleted" lherzolite, this configuration suggests that the old, LREE-depleted layer is sandwiched between relatively undepleted mantle zones. Alternatively, if our samples do not match the specific depth assignments of Nixon and Boyd, the mantle in this general region might be composed of a bunch of pockets of depleted and relatively undepleted material. If PHN-3852 was contaminated or isotopically exchanged with the alnoite, no conclusions can be drawn

The lateral extensions and volume of these mantle regions are not known; however, the undepleted zone (close to bulk earth concentrations of LIL elements) as sampled by the alnoite and basalt is expected to be a large volume as it is the mantle souree for the OJP. The plateau occupies an area of $\sim 10^{6} \mathrm{~km}^{2}$ and has a thickness of $25-40 \mathrm{~km}$ [Coleman and Packham, 1976; Furumoto et al., 1973]. Assuming that the plateau is all basalt and that it is derived from an approximately undepleted mantle source, then the volume of rock needed to produce the plateau (assuming 5-25\% partial melting) is $5 \times 10^{8} \mathrm{~km}^{3}$ to $10^{8} \mathrm{~km}^{3}$. This would correspond to an originally undepleted mantle layer $\sim 500-100 \mathrm{~km}$ thick. The residue after production of the OJP would be depleted. We attribute the young alnoite magma to a small degree of partial melting of some part of this zone which had not been depleted.

The isotopic composition of the undepleted Malaitan mantle ( $\left(\varepsilon_{\mathrm{Sr}} \sim 0 ; \varepsilon_{\mathrm{Nd}} \sim 3.5\right)$ is an unusual combination, incompatible with the known major mantle or crustal reservoirs [DePaolo and Wasserburg, 1979a] (excluding oceanic islands, whose mantle source is tectonically not yet well defined). The $\varepsilon_{\mathrm{Nd}}$ value is distinct from the bulk earth values and is compatible with a LREE-depleted reservoir with $\left\langle f^{\mathrm{Sm} / \mathrm{Nd}} T\right\rangle=$ $\varepsilon_{\mathrm{Nd}} / Q \sim 0.14$, where the angle brackets represent the average values. Assuming it represents a depleted mantle with $f^{\mathrm{Sm} / \mathrm{Nd}}$ of $\sim 0.2$, this corresponds to an effective age of $\sim 0.7$ aeon for the depletion event, which is much younger than that of the MORB source ( $\sim 1.8$ aeons according to Jacobsen and Wasserburg [1979a]) or to an older, much less depleted source with smaller $f^{\mathrm{Sm} / \mathrm{Nd}}$. The $\varepsilon_{\mathrm{Sr}}$ value indicates an essentially undifferentiated reservoir remarkably close to the value for UR. The UR value has been obtained indirectly as the intersection of $\varepsilon_{\mathrm{Nd}}=$ 0 with the mantle array [DePaolo and Wasserburg, 1976b; O'Nions et al., 1977] and is not so precisely fixed. It is therefore legitimate to consider another value for the present bulk earth ${ }^{87} \mathrm{Sr} /{ }^{86} \mathrm{Sr}$ composition. Assuming that the Malaita $\mathrm{Sr}$ isotopic composition is a result of a depletion with parameters determined by the Sm-Nd systematics, then the calculated $\left({ }^{87} \mathrm{Sr} /{ }^{86} \mathrm{Sr}\right) \mathrm{UR}$ in this case is $\sim 0.7053$. However, if we accept the bulk earth composition value as 0.7045 , then there are two possible explanations for the observed isotopic composition.
1. It is an ancient mantle reservoir with a unique composition that has not been previously identified.

2. It is a mixture of known reservoirs.

The possibility that the Malaita mantle is an old reservoir implies that it has chemically evolved from primordial composition $\left(\varepsilon_{\mathrm{Sr}}=\varepsilon_{\mathrm{Nd}}=0\right)$ to yield $\varepsilon_{\mathrm{Nd}} \sim 3.5$ and $\varepsilon_{\mathrm{Sr}} \sim 0$. The differentiation trend had to be such that it would cause a LREE depletion without fractionating $\mathrm{Rb} / \mathrm{Sr}$. As $\mathrm{Rb}$ is highly fractionated in partial melting or in volatile phases, such a mechanism is very implausible.

The possibility that the source is produced as a result of mixing was examined. The end-members that were considered are depleted mantle and continental crust reservoirs. The concentration and isotopic parameters for those reservoirs have been estimated previously but are not precisely known. Jacobsen and Wasserburg [1979a] suggested a set of $\mathrm{Rb}-\mathrm{Sr} / \mathrm{Sm}$ Nd parameters for the present crust and depleted mantle, a set which is consistent with a primitive composition (CHUR and UR) prior to the separation of the crust from the mantle. This self-consistent (but not necessarily correct) set of parameters (Table 2) serve as a basis for the mixing calculations. The distribution of the elements among upper and lower crust was constructed (Table 2) assuming that (1) Sm-Nd levels are the same for both reservoirs [see Jacobsen and Wasserburg, 1979a, Table 6], (2) $\varepsilon_{\text {upper crust }}$ Sr $=163$ (average continental runoff, Veizer and Compston [1974]), and (3) $R b_{\text {upper crust }}=2$ $\times \mathbf{R} \mathbf{b}_{\text {lower crust. }}$.

The isotopic composition of the mixture of the different crustal reservoirs and depleted mantle was calculated using the mixing equation [Steiger and Wasserburg, 1966]

$$
\varepsilon^{\alpha} \operatorname{mix}=\frac{x_{1}[\alpha]_{1}\left[\varepsilon^{\alpha}\right]_{1}+\left(1-x_{1}\right)[\alpha]_{2}\left[\varepsilon^{\alpha}\right]_{2}}{x_{1}[\alpha]_{1}+\left(1-x_{1}\right)[\alpha]_{2}}
$$

where $[\alpha]$ is the concentration of $\mathrm{Nd}$ or $\mathrm{Sr}$ and $x_{1}$ is the weight fraction of component 1 in the binary mixture [DePaolo and Wasserburg, 1979a].

The resultant $\varepsilon_{\mathrm{Nd}}-\varepsilon_{\mathrm{Sr}}$ mixing curves are shown in Figure 5. The Malaitan isotopic composition $\left(\varepsilon_{\mathrm{Nd}}=3.5, \varepsilon_{\mathrm{Sr}}=0\right.$ ) falls on the mixing curve of upper crust with depleted mantle at $1 \%$ upper crust. It should be noted that (1) as Sm and Nd content is assumed to be the same for both crustal reservoirs, the difference between the mixing curves depends on the $\mathrm{Rb}-\mathrm{Sr}$ fractionation alone, (2) at a level of $\sim 1 \%$ upper crust, $\varepsilon_{\mathrm{mit}}^{\mathrm{st}}$ and $\varepsilon_{\text {mix }}{ }^{N d}$ will not change much if $\varepsilon_{\text {upper crust }}$ or $\varepsilon_{\text {upper crust }}$ used in the model are somewhat different; for $x_{1}=0.99, \varepsilon_{\text {mix }} \mathrm{sr}$ will change by only $1.5 \mathrm{\varepsilon u}$ per $10 \mathrm{\varepsilon u}$ change of $\varepsilon_{\mathrm{upper} \text { erust }} \mathrm{Sr}$ and $\varepsilon_{\text {mix }}{ }^{\text {Nd }}$ will change by $0.24 \mathrm{eu}$ per 1 eu change of $\varepsilon_{\text {lower crust }}{ }^{\mathrm{Nd}}$, and (3) the shape of the mixing curves is a function of $K$ $\left(K=(\mathrm{Sr} / \mathrm{Nd})_{1} /(\mathrm{Sr} / \mathrm{Nd})_{2}\right)$. For $K<1$ the curve is concave downward, and if that was the case for the lower crust, then the Malaitan result (Figure 5) would have lain close to the lower crust mixing curve and similarly for the bulk crust. However, the precise $K$ values are not well known.

The conclusion from the mixing calculations seems to be that it is possible to obtain a reservoir with the Malaitan isotopic characteristics by mixing depleted mantle and crustal reservoir at a ratio of $100: 1$. By using a self-consistent set of $\mathrm{Rb}-\mathrm{Sr} / \mathrm{Sm}-\mathrm{Nd}$ parameters for the crust and mantle and assuming $\varepsilon_{\text {upper crust }} \mathrm{Sr}=\varepsilon_{\mathrm{average} \mathrm{continental} \mathrm{runof} \mathrm{Sr}}$ and $\mathbf{R} \mathbf{b}_{\text {upper crust }}=$ $2 \times R b_{\text {lower crust }}$, it appears that the upper crust is the better reservoir for the mixture. The resultant concentrations of this mixture are listed in Table 2. The $f^{\mathrm{Sm} / \mathrm{Nd}}$ and $f^{\mathrm{Rb} / \mathrm{Sr}}$ of the mixture are 0.07 and 0 , respectively. Such reservoirs will change in $\varepsilon_{\mathrm{Nd}}$ by less than $0.2 \varepsilon \mathrm{u}$ over 0.1 aeon, a time span 
TABLE 2. Rb-Sr and Sm-Nd Data Used for a Mixing Model for the Alnoite Mantle Source

\begin{tabular}{|c|c|c|c|c|c|c|c|c|}
\hline Reservoir & $\begin{array}{l}\text { Sm, } \\
\text { ppm }\end{array}$ & $\begin{array}{l}\text { Nd, } \\
\text { ppm }\end{array}$ & $\begin{array}{l}\text { Rb, } \\
\text { ppm }\end{array}$ & $\begin{array}{l}\mathrm{Sr}, \\
\text { ppm }\end{array}$ & $\varepsilon_{\mathrm{Sr}}(0)$ & $\varepsilon_{\mathrm{Nd}}(0)$ & $f^{\mathbf{R b} / \mathbf{S r}}$ & $f^{\mathrm{Sm} / \mathrm{Nd}}$ \\
\hline Depleted mantle & 0.32 & 0.82 & 0.04 & 15.8 & -27 & 10 & -0.9 & 0.225 \\
\hline Bulk crust & 5.0 & 26 & 33 & 370 & 65.5 & -17.8 & 2.18 & -0.4 \\
\hline Upper crust & 5.0 & 26 & $50^{*}$ & $270 \dagger$ & $163 \ddagger$ & -17.8 & $5.4 \dagger$ & -0.4 \\
\hline Lower crust & 5.0 & 26 & $24^{*}$ & $430 \dagger$ & $28 t$ & -17.8 & $0.9 t$ & -0.4 \\
\hline $\begin{array}{l}\text { A mixture of } 1 \% \text { upper crust } \\
\text { with } 99 \% \text { depleted mantlet }\end{array}$ & 0.37 & 1.1 & 0.5 & 18 & 0 & 3.3 & 0 & 0.07 \\
\hline
\end{tabular}

Data taken from Jacobsen and Wasserburg [1979a] unless otherwise indicated.

*Assuming $\mathbf{R b}_{\text {upper crust }}=2 \times \mathbf{R b}_{\text {lower crust }}$ and Mass $_{\text {lower crust }}=1.5$ mass $_{\text {upper crust }}$

$\dagger$ Result of the data and assumptions used by Jacobsen and Wasserburg [1979a, b].

$\ddagger$ Average continental runoff [Veizer and Compston, 1974].

covering the formation of the OJP and the alnoite. By the assumptions, $\varepsilon_{\mathrm{Sr}}$ will not change with time.

As the volume of mantle involved in the source of the OJP is $5 \times 10^{8}-10^{8} \mathrm{~km}^{3}$, this requires $5 \times 10^{6}-10^{6} \mathrm{~km}^{3}$ of crustal contribution. That corresonds to a block of $10^{4}-10^{5} \mathrm{~km}^{2}$ of continental crust of $\sim 40 \mathrm{~km}$ thickness. As the alnoite and basalt were derived over a time span of $\sim 65$ m.y. and from a large volume of parental material, it appears that the source must be relatively homogeneous in order to explain the isotopic data. This imposes a difficulty with mixing the proposed components. A mechanical blend of mantle and crust is not an attractive process as we would expect a wide range of isotopic composition in the partial melting of such mixtures. There is no isotopic evidence of the result of partial melting of a crustal end-member which might result from a purely coarse scale mechanical "mixture." A large-scale metasomatism of the mantle with fluids originated from the crustal component which could mobilize and reequilibrate the trace elements preferentially over large distances seems to be a way to obtain a rather homogeneous isotopic reservoir from such a "mixture." The crustal component must, nevertheless, have reached a depth of at least $100 \mathrm{~km}$.

The source for continental blocks in the West Pacific is somewhat problematic, as has already been pointed out by Carlson et al. [1980]. Nur and Ben Avraham [1977, 1982] call for Pacifica to supply pieces of continental crust, which now appear as oceanic plateaus in the West Pacific. The results of

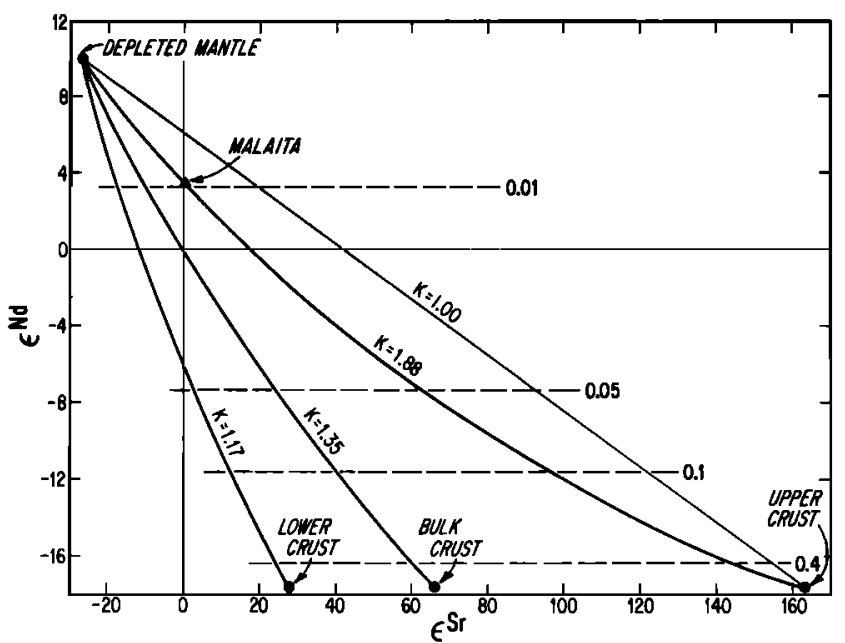

Fig. 5. The $\varepsilon_{\mathrm{Nd}}-\varepsilon_{\mathrm{Sr}}$ mixing curves for depleted mantle and (1) lower crust, (2) upper crust, and (3) bulk crust. $\mathrm{Rb}-\mathrm{Sr}$ and $\mathrm{Sm}-\mathrm{Nd}$ characteristics are given in Table $2\left(K=(\mathrm{Sr} / \mathrm{Nd})_{\text {depleted mantle }} /(\mathrm{Sr} / \mathrm{Nd})\right)$. our study are clearly incompatible with the OJP itself being a piece of old continent. However, as indicated above, such a small block of old continental crust might have been involved in producing the mantle source for the OJP if a homogenization process with large volumes of depleted mantle could be found. Another alternative is that young continental block (a ready-made blend of old crustal and young arc material) with bulk LIL element characteristics close to the average earth was subducted under the oceanic lithosphere. This could then provide an appropriate isotopic and chemical source.

DePaolo $[1980,1981]$ has shown that some plutonic rocks in the Sierra Nevada and Peninsular ranges of California are the product of partial melting of old continental crust mixed with younger magmas derived from the depleted mantle. These composite magmas show a wide range in $\varepsilon_{\mathrm{Nd}}$ and $\varepsilon_{\mathrm{Sr}}$, but several of them have isotopic compositions similar to the alnoite and basalt from Malaita. The characteristics of the two mixing mechanisms outlined above are different only in requiring mixing at near crustal levels rather than at substantial depths within the mantle. The possibility of producing a "wellmixed" smaller crustal block prior to subduction appears simpler than homogenizing crustal material with large volumes within the mantle. In any event a narrowly defined isotopic composition as a result of mixing is not readily explained.

In conclusion, we infer that the alnoites and basalts of the OJP are derived by partial melting of a lithic reservoir that is relatively undepleted $\left(\langle f T\rangle_{\mathrm{Nd}} \sim 0.1\right)$. This reservoir may be composed of a mixture of $\sim 99 \%$ of depleted mantle $\left(\langle f T\rangle_{\mathrm{Nd}} \sim 0.4\right)$ with $\sim 1 \%$ of enriched continental blocks $\left(\langle f T\rangle_{\mathrm{Nd}} \sim-0.6\right.$.). This continental block or blocks $\left(\sim 10^{6}\right.$ $\mathrm{km}^{3}$ ) would then have been entrained by downward moving, depleted upper mantle to a depth of at least $100 \mathrm{~km}$. Partial melting of these blocks with very extensive and large-scale metasomatic exchange with the depleted oceanic mantle component produce the observed isotopic signature. Alternatively, the reservoir might consist of deeply subducted young continental blocks with the appropriate isotopic signature. In this case the volume of the block would be relatively small. The presence of continental blocks in the ocean sector during Mesozoic time may be related to Gondwanaland fragmentation. It is possible that this mechanism of relatively large-scale homogenization of trace elements by volatile metasomatism could also provide the common characteristics of continental flood basalts $\left(\varepsilon_{\mathrm{Nd}} \sim 0\right)$ which were used by DePaolo and Wasserburg [1979b] and Wasserburg and DePaolo [1979] to infer the existence of an undifferentiated layer in the lower mantle. This model has recently been contested by White and Hofmann [1982], who have argued for subducted continental frag- 
ments as a major component in the source of oceanic volcanics. The connection between the alnoite source and that of ocean islands cannot be made; however, the trend of oceanic island basalts toward enriched (or at least undepleted) parent reservoirs is the same as found by us for the sources of the OJP.

From this cursory investigation it appears that intensive studies of isotopic characteristics at localities where some knowledge of mantle "lithic stratigraphy" is known may permit a better understanding of the mantle "isotopic stratigraphy."

Acknowledgments. We wish to thank H. G. Stosch for an extensive and scholarly review that has been of great value to us. A second, anonymous reviewer made several very useful criticisms. This paper was supported by the National Aeuronautics and Space Administration grant NGL 05-002-188. Contribution 3844 (429) of the Division of Geological and Planetary Sciences, California Institute of Technology, Pasadena, California. The criticisms of R. Jones, $M$. Thirlwall, and $\mathbf{R}$. Volmer are gratefully acknowledged.

\section{REFERENCES}

Allen, J. B., and T. Deans, Ultrabasic eruptives with alnoitickimberlitic affinities from Malaita, Solomon Islands, Mineral. Mag., 34, 16-34, 1965.

Basu, A. R., and M. Tatsumoto, Nd-isotopes is selected mantlederived rocks and minerals and their implications for mantle evolution, Contrib. Mineral. Petrol., 75, 43-54, 1980.

Boettcher, A. L., J. R. O'Neil, K. E. Windon, D. C. Stewart, and H. G. Wilshire, Metasomatism of the upper mantle and the genesis of kimberlites and alkali basalts, in The Mantle Sample: Inclusions in Kimberlites and Other Volcanics, edited by F. R. Boyd and H. O. A. Meyer, pp. 173-182, AGU, Washington, D. C., 1979.

Carlson, R. L., N. I. Christensen, and R. P. Moor, Anomalous crustal structures in ocean basins: Continental fragments and oceanic plateaus, Earth Planet. Sci. Lett., 51, 171-180, 1980.

Coleman, P. J., and L. W. Kroenke, Subduction without volcanism in the Solomon Islands arc, Geo Mar. Lett., 1, 129-134, 1981.

Coleman, P. J., and G. H. Packham, The Melaneisan botderlands and India-Pacific plates boundary, Earth Sci. Rev., 12, 197-233, 1976.

Davis, G. L., Zircons from the mantle, U.S. Geol. Surv. Open File Rep., 78-701, 86-88, 1978.

DePaolo, D. J., Study of magma sources, mantle structure and the differentiation of the earth, using variations of ${ }^{143} \mathrm{Nd} /{ }^{144} \mathrm{Nd}$ in igneous rocks, Ph.D. thesis, 360 pp., Calif. Inst. of Technol., Pasadena, 1978.

DePaolo, D. J., Sources of continental crust: Neodymium isotope evidence from the Sierra Nevada and Peninsular ranges, Science, 209, 684-687, 1980.

DePaolo, D. J., A neodynium and strontium isotopic study of Mesozoic calc-alkaline granitic batholiths of the Sierra Nevada and Peninsular ranges, California, J. Geophys. Res., 86, 10470-10488, 1981.

DePaolo, D. J., and G. J. Wasserburg, Inferences about magma sources and mantle structure from variations of ${ }^{143} \mathrm{Nd} /{ }^{144} \mathrm{Nd}$, Geophys. Res. Lett., 3, 743-746, $1976 a$.

DePaolo, D. J., and G. J. Wasserburg, Inferences about magma sources and mantle structure from variations of ${ }^{143} \mathrm{Nd} /{ }^{144} \mathrm{Nd}$, Geophys. Res. Lett., 3(12), 743-746, $1976 b$.

DePaolo, D. J., and G. J. Wasserburg, Petrogenetic mixing models and Nd-Sr isotopic patterns, Geochim. Cosmochim. Acta, 43, 615$627,1979 a$.

DePaolo, D. J., and G. J. Wasserburg, Neodymium isotopes in flood basalts from the Siberian Platform and inferences about their mantle sources, Proc. Natl. Acad. Sci. USA, 76(7), 3056-3060, $1979 b$.

Furumoto, A. S., W. A. Weibenga, J. P. Webb, and G. H. Sutton, Crustal structure of the Hawaiian archipelago, northern Melanesia and the central Pacific basin by seismic refraction methods, Tectonophysics, 20, 153-164, 1973.

Gast, P. W., Trace element fractionation and the origin of tholeiitic and alkaline magma types, Geochim. Cosmochim. Acta, 32, 10571086, 1968.

Goldberg, E. D., G. Koide, R. A. Schmitt, and R. H. Smith, Rare earth distributions in the marine environment, J. Geophys. Res., 68, 4209-4217, 1963.
Harrison, W. J., Partitioning of REE between minerals and coexisting melts during partial melting of a garnet lherzolite, Am. Mineral., 66, $242-259,1981$.

Haskin, L. A., F. A. Frey, R. A. Schmitt, and R. H. Smith, Meteoritic, solar and terrestrial rare earth element distributions, Phys. Chem. Earth, 7, 167-321, 1966.

Hawkesworth, C. J., G. J. Norry, J. C. Roddick, and R. Vollmer, ${ }^{143} \mathrm{Nd} /{ }^{144} \mathrm{Nd}$ and ${ }^{86} \mathrm{Sr} /{ }^{86} \mathrm{Sr}$ ratios from the Azores and their significance in LIL-element enriched mantle, Nature, 280, 28-31, 1979.

Hughes, C. W., and C. C. Turner, Upraised Pacific Ocean floor, southern Malaita, Solomon Islands, Geol. Soc. Am. Bull, 88, 412$424,1977$.

Hussong, D. M., L. K. Wippeman, and L. W. Kroenke, The crustal structure of the Ontong Java and Manchiki ocean plateaus, $J$. Geophys. Res., 84, 6003-6010, 1979.

Jacobsen, S. B., and G. J. Wasserburg, The mean age of mantle and crustal reservoirs, J. Geophys. Res., 84, 7411-7427, $1979 a$.

Jacobsen, S. B., and G. J. Wasserburg, Nd and Sr isotopic study of the Bay of Islands ophiolite complex and the evolution of the source of the mid-ocean ridge basalts, J. Geophys. Res., 84, 7429$7445,1979 b$.

Jacobsen, S. B., and G. J. Wasserburg, Sm-Nd isotopic evolution of chondrites, Earth Planet. Sci. Lett., 50, 139-155, 1980.

Kay, R. W., and P. W. Gast, The rare earth content and origin of alkali-rich basalts, J. Geol., 81(6), 653-682, 1973.

Kramers, J. D., C. B. Smith, N. P. Lock, R. S. Harmon, and F. R. Boyd, Can kimberlites be generated from an ordinary mantle?, Nature, 291, 53-56, 1981.

Kroenke, L. W., Geology of the Ontong Java Plateau, Rep. H10-72-5, 119 pp., Hawaii Inst. of Geophys., Univ. of Hawaii, Honolulu, 1972.

Kroenke, L. W., Origin of continents through development and coalescence of oceanic flood basalt plateaus, Eos Trans. $A G U, 55,443$, 1974.

Mason, B. (Ed.), Handbook of Elemental Abundances in Meteorites, Gordon and Breach, New York, 1971.

McCulloch, M. T., and G. J. Wasserburg, Sm-Nd and Rb-Sr chronology of continental crust formation, Science, 200(4345), 1003-1011, 1978.

Mysen, B. O., Trace-element partitioning between garnet peridotite minerals and water-rich vapor: Experimental data from 5 to 30 kbar, Am. Mineral., 64, 274-287, 1979.

Nixon, P. H., Kimberlites in the southwest Pacific, Nature, 287, $718-$ 720,1980

Nixon, P. H., and F. R. Boyd, Garnet-bearing lherzolites and discrete nodule suites from the Malaita alnoite, Solomon Islands, SW Pacific, and their bearing on oceanic mantle composition and geotherm, in The Mantle Sample: Inclusions in Kimberlites and Other Volcanics, edited by F. R. Boyd and H. O. A. Meyer, pp. 400-423, AGU, Washington, D. C., 1979.

Nixon, P. H., and P. J. Coleman, Garnet-bearing lherzolites and discrete nodule suites from the Malaita alnoite, Solomon Islands, and their bearing on the nature and the origin of the Ontong Java Plateau, Bull. Aust. Soc. Explor. Geophys., 9(3), 103-107, 1978.

Nixon, P. H., R. H. Mitchell, and N. Rogers, Petrogenesis of alnoitic rocks from Solomon Islands, Melanesia, Mineral. Mag., 43, 587$596,1980$.

Nixon, P. H., N. W. Rogers, I. L. Gibson, and A. Grey, Depleted and fertile mantle xenoliths from southern African Kimberlites, Annu. Rev. Earth Planet. Sci., 9, 285-309, 1981.

Nur, A., and Z. Ben Avraham, Lost Pacifica continent, Nature, 270(5632), 41-43, 1977.

Nur, A., and Z. Ben Avraham, Oceanic plateaus, the fragmentation of continents, and mountain building, J. Geophys. Res., 87, 3644-3661, 1982.

O'Nions, R. P., P. J. Hamilton, and N. M. Evenson, Variations in ${ }^{143} \mathrm{Nd} /{ }^{144} \mathrm{Nd}$ and ${ }^{87} \mathrm{Sr} /{ }^{86} \mathrm{Sr}$ ratios in oceanic basalts, Earth Planet. Sci. Lett., 34, 13-22, 1977.

Papanastassiou, D. A., D. J. DePaolo, and G. J. Wasserburg, Rb-Sr and Sm-Nd chronology and genealogy of basalts from the Sea of Tranquility, Proc. Lunar Sci. Conf., 8th, 1639-1672, 1977.

Richard, P., N. Shimizu, and C. J. Allegre, ${ }^{143} \mathrm{Nd} /{ }^{144} \mathrm{Nd}$, a natural tracer, an application to oceanic basalts, Earth Planet. Sci. Lett., 31, 269-278, 1976.

Rickwood, F. K., Geology of the Island of Malaita, Colon. Geol. Miner. Resour., 6, 300-305, 1957.

Shimizu, N., Rare earth elements in garnets and clinopyroxenes from 
garnet lherzolite nodules in kimberlites, Earth Planet. Sci. Lett., 25, 26-32, 1975.

Steiger, R. H., and G. J. Wasserburg, Systematics in the ${ }^{208} \mathrm{~Pb}-{ }^{232} \mathrm{Th}$, ${ }^{207} \mathrm{~Pb}^{235} \mathrm{U}$ and ${ }^{206} \mathrm{~Pb}-{ }^{238} \mathrm{U}$ systems, $J$. Geophys. Res., $71,6065-$ $6090,1966$.

Tatsumoto, M., C. E. Hedge, and A. E. J. Engel, K, Rb, Sr, Th, U and ${ }^{87} \mathrm{Sr} /{ }^{86} \mathrm{Sr}$ in oceanic tholeiitic basalt, Science, 150, 886-888, 1965.

Veizer, J., and W. Compston, ${ }^{87} \mathrm{Sr} /{ }^{86} \mathrm{Sr}$ composition of seawater during the Phanerozoic, Geochim. Cosmochim. Acta, 38, 1461-1484, 1974.

Wasserburg, G. J., and D. J. DePaolo, Models of earth structure inferred from neodymium and strontium isotropic abundances, Proc. Natl. Acad. Sci. USA, 76(8), 3594-3598, 1979.

Wasserburg, G. J., S. B. Jacobsen, D. J. DePaolo, M. T. McCulloch, and T. Wen, Precise determination of $\mathrm{Sm} / \mathrm{Nd}$ ratios, $\mathrm{SM}$ and $\mathrm{Nd}$ isotopic abundances in standard solutions, Geochim. Cosmochim. Acta, 45, 2311-2323, 1981.

Wendlandt, R. F., and W. J. Harrison, Rare earth partitioning be- tween immiscible carbonate and silicate liquids and $\mathrm{CO}_{2}$ : Results and implications for the formation of light rare earth-enriched rocks, Contrib. Mineral. Petrol., 69, 409-419, 1979.

White, W. M., and A. W. Hofmann, Sr and Nd isotope geochemistry of oceanic basalts and mantle evolution, Nature, 296, 821-825, 1982.

M. Bielski-Zyskind, 3 William Street, Highland, NJ 07739.

P. H. Nixon, Department of Earth Sciences, University of Leeds, Leeds LS2 9JT, Great Britain.

G. J. Wasserburg, Lunatic Asylum of the Charles Arms Laboratory, Division of Geological and Planetary Sciences, California Insitute of Technology, Pasadena, CA 91125.

(Received April 21, 1983;

revised December 2, 1983;

accepted December 6, 1983.) 